logos_i_ethos_2013_1_(34), s. 149-169

Leszek Augustyn

\title{
Spór o Kartezjusza. Polemika B. Wyszesławcewa z J. Maritainem, dotycząca znaczenia filozofii Kartezjusza dla nowożytnej duchowości europejskiej'
}

Warunkiem wszelkich istotnych dyskusji intelektualnych, w tym przede wszystkim sporów filozoficznych, jest spotkanie myślicieli, którzy nie tylko różnią się co do zajmowanych przez siebie stanowisk, ale w tej różnicy łączą się na gruncie wspólnej im troski o uczciwość intelektualną i praw-

Leszek Augustyn - filozof i religioznawca, doktor nauk humanistycznych, adiunkt w Instytucie Filozofii Uniwersytetu Jagiellońskiego. Zajmuje się historią XIX- i XX-wiecznej filozofii rosyjskiej, historią idei, filozofią religii i filozofią społeczną. dę filozoficzną. Chodzi zatem nie tylko o spotkanie fizyczne, ograniczone miejscem i czasem (to wszak nie jest konieczne), ale też o zaistnienie samych warunków dla prawdziwej rozmowy, wyznaczenie pewnej mentalnej, intelektualnej - niechby i wirtualnej - przestrzeni. To oczywiście - nader „idealistyczne” założenia. W rzeczywistości odczucia bywają różne. Otóż o jednym z takich interesujących nas „intelektualnych wydarzeń” wspominała żona filozofa, Raïssa Maritain:

Widzę Jacques’a u Bierdiajewa, stojącego przed filozofami rosyjskimi i francuskimi [...]. We francusko-rosyjskim studio, jak w ostatni wtorek, wystawionego na sprzeciwy ze strony filozofów rosyjskich i naukowców francuskich oraz idiotów dziennikarzy (obrońców humanizmu, jak są uprzejmi twierdzić). Wszędzie oczekuje się od niego prawdziwego słowa, rzeczywiście katolickiego, albo żeby je przyjąć, albo żeby je okrutnie zaatakować2.

1 Artykuł powstał na podstawie tekstu wystąpienia wygłoszonego podczas IX Polskiego Zjazdu Filozoficznego (17-21 IX 2012, Gliwice-Katowice-Wisła).

2 R. Maritain, Dziennik, tłum. M. Żurowska, Warszawa 2012, s. 176. 
Przywołana dyskusja odbyła się w Paryżu 27 stycznia 1931 roku. Było to kolejne spotkanie z cyklu Studio franco-russe, któremu przewodniczył Wsevolod de $\operatorname{Vogt}^{3}$. Wzięli w nim udział przedstawiciele emigracyjnej inteligencji rosyjskiej oraz wybitni intelektualiści francuscy (w tym, oczywiście, filozofowie). Publikacja tekstu obydwu wystąpień oraz zapisu wywołanej przez nie dyskusji miała miejsce na łamach „Cahiers de la Quinzaine”. . Podczas spotkania Jacques Maritain wygłosił odczyt zatytułowany Descartes et l'esprit cartésien ${ }^{5}$, Borys Wyszesławcew zaś odpowiedział wystąpieniem Descartes et la philosophie moder$n e$. Zgodnie z ogólnym zamysłem założycieli Studio franco-russe było to naświetlenie wskazanego problemu $\mathrm{z}$ dwóch odmiennych perspektyw: francuskiej i rosyjskiej. W takiej bowiem „bilateralnej”, międzynarodowej i międzykulturowej formule dyskusji dopatrywano się szansy na poszerzenie, pogłębienie i wzbogacenie świadomości poznawczej, pełniejsze zrozumienie konkretnej problematyki, ale także wzajemne zbliżenie się dwóch europejskich kultur, dwóch odmiennych podejść do tradycji kulturalnych i filozoficznych, własnych, obcych i uniwersalnych. Tym razem przedmiotem owego namysłu było zagadnienie kartezjańskie: Kartezjusz i kartezjanizm.

3 To właśnie Wsevolod de Vogt wraz z Robertem Sébastien byli inicjatorami i prowadzącymi kolejne spotkania w ramach Studio franco-russe. Przywoływane spotkanie było dwunastym $\mathrm{z}$ tego cyklu.

4 J. Maritain, B. Vycheslavzeff, Descartes. Textes suivis de débats au Studio franco-russe, „Cahiers de la Quinzaine”, Paris 1931 (zeszyt nr 5, seria nr 21, 18 II 1931). Przedruk tekstów i opracowanie: Le Studio Franco-Russe. 1929-1931. Textes réunis et présentés par Leonid Livak. Sous la rédaction de Gervaise Tassis, Toronto 2005 (Toronto Slavic Library, vol. 1). W niniejszym szkicu korzystamy z tego ostatniego wydania.

Trzeba podkreślić, że tekst tego wystąpienia posłużył Maritainowi za podstawę rozdziału V. książki Le songe de Descartes, Paris 1932 (wspomniany rozdział nosi nazwę L’héritage cartésien). W swoim czasie poglądy w niej wyłożone wykazywały charakter dość kontrowersyjny. Należy też przypomnieć, że główne tezy zawarte w obu publikacjach zostały sformułowane już kilka lat wcześniej, a mianowicie w książce Trzej reformatorzy (1925). 


\section{Maritain i plagi kartezjanizmu}

We wspomnianym wystąpieniu Maritain zastrzegał się, że interesuje go przede wszystkim wpływ Kartezjusza na kulturę. Niemniej jednak, by móc osiągnąć zamierzony cel, musiał wskazać na filozoficzny charakter owych - jak sądził, nie dość dotychczas zauważanych i podkreślanych - tendencji w kulturze europejskiej. $Z$ tego więc punktu widzenia starał się prześledzić i poddać zasadniczej krytyce te przesłanki filozoficzne i ich kulturalne konsekwencje, które nie tylko przesądziły o charakterze samego stanowiska kartezjańskiego, ale ponadto nadały trwały kształt europejskiej, nowożytnej kulturze.

Jest rzeczą ogólnie znaną, że swój pierwotny impuls Kartezjuszowski „system rozumu” zawdzięcza „objawieniu we śnie”. Chodzi o słynny sen Kartezjusza, który nawiedził początkującego filozofa-żołnierza w nocy 10 listopada 1619 roku. Sprawą zasadniczą był w nim problem nauki uniwersalnej, scientia mirabilis, która w sposób niebudzący już wątpliwości ujmowałaby „system świata”. W przekonaniu Maritaina mamy w tym przypadku do czynienia z "prywatnym objawieniem filozofa”. Zapytuje zatem: czy nie jest czymś zawstydzającym dla racjonalizmu, że zrodził się ze snu? Być może należałoby też zapytać, czy Geniusz, który nawiedził Kartezjusza owej pamiętnej nocy, nie był kuzynem le malin Génie z późniejszych Medytacji (1641)??

Za sprawą Kartezjusza nastąpiło formalne zerwanie z klasycznie rozumianą tradycją filozoficzną. Nie ulega przy tym wątpliwości, że $\mathrm{w}$ przypadku kartezjanizmu mamy do czynienia $\mathrm{z}$,problemem początku”; co więcej, każdy współczesny filozof nolens volens jest kartezjaninem w tym sensie, iż przyjmuje absolutny punkt wyjścia dla własnej myśli i swej każdorazowo odbudowywanej wizji świata. Pod tym chociażby względem rozziew pomiędzy przednowożytnością i czasami nowożytnymi pozostaje otwarty. Nieco inną natomiast rzeczą jest

J. Maritain, Le songe..., dz. cyt., s. 27.

Tenże, Descartes et l'esprit cartésien, [w:] Le Studio Franco-Russe, dz. cyt., s. 405; por. tenże, Le songe..., dz. cyt., s. 7 i 254. 
kontynuacja materialna (wyznaczona pewnymi zasadami i określonymi treściami), jaka zachodzi między niektórymi wątkami rodem ze starej scholastyki i rodzącym się w opozycji do niej kartezjanizmem. W późniejszym okresie zostały one jednak zapomniane. Jakkolwiek by zatem nie wyznaczać zakresu owej ciągłości, to i tak pozostaje bezspornym faktem, że na miejsce autorytetu prawdy ponadludzkiej, wiecznej i niezmiennej, odzwierciedlonej w tradycji filozoficznej, wkroczyło nowe kryterium oczywistości (zarówno zawierające się $w$ umyśle-podmiocie, jak i istniejące dla podmiotu). W ten więc sposób ustanowiona została zasadnicza przesłanka teoretyczna i nastąpił też faktyczny początek nowożytnego indywidualizmu.

Tezy francuskiego filozofa dają się sprowadzić do trzech zagadnień: 1) stosunku myśli do bytu; 2) problemu hierarchii intelektualnej i znaczenia świadomości; 3) koncepcji człowieka.

Ad 1. Chociaż Kartezjusz wierzy jeszcze w rzeczy i chce je poznawać, to w istocie owymi rzeczami stają się dlań idee, i w konsekwencji sam rozum kartezjański poznaje tylko idee. Prawdziwość zaś idei została zagwarantowana przez „prawdziwego”, czyli ze swej istoty „niezwodzącego” Boga. Ale w ten sposób system kartezjański zawisa w powietrzu: nie dowodzi się bowiem istnienia Boga z Jego idei - Maritain, wierny tomizmowi, odrzuca zasadność dowodu ontologicznego. To stąd zatem bierze swój początek idealizm myśli nowożytnej, który wnosi do europejskiej kultury „antropocentryczny optymizm myśli”. Niemniej jednak optymizm ten jest samobójczy, gdyż dokonując zerwania myśli z bytem (popełniając swoisty „grzech ontologiczny”), sprawia, iż w rzeczywistości człowiek staje się centrum, ale jest to „centrum pustyni”.

Ad 2. Uznane w filozofii kryterium oczywistości, odnoszące się do treści poznania, zmienia u Kartezjusza swe znaczenie; nie stanowi już właściwości rzeczy, lecz dotyczy idei. Z obiektywizmu rzeczy przenosi się w subiektywizm świadomości ludzkiej. Następuje zniesienie metafizycznej tajemnicy świata, dotychczas ujmowanej w teologicznej mądrości: świat, a wraz z nim i człowiek, stają się rzeczywistością czysto naturalną. Dokonuje się zatem sekularyzacja mądrości. Tym samym bezwzględnie zaczyna rządzić rozum, natomiast wiara przyjmuje charakter 
czysto woluntarystyczny. Co prawda, Kartezjusz pozostaje fideistą (Bóg jest mu potrzebny ze względów tak osobistych, jak i filozoficznych), ale łączy tę postawę z antyteologizmem; rzeczy boskie i odnosząca się do nich teologia nie są już bowiem sprawą nauki. Wiara łączy się z wolą, ale ta ostatnia pozostaje przecież poznawczo ślepa, i odtąd też fides NON querens intellectum ${ }^{8}$. Twórca nowożytnego racjonalizmu zdaje się więc otwierać przestrzeń dla agnostycyzmu. Jakkolwiek uznając ideę Boga za jasną i wyraźną, samowystarczalną dla istnienia swego przedmiotu, staje on zarazem na stanowisku ontologizmu i panteizmu; chociaż na gruncie tych samych założeń nie do końca wiadomo, jak połączyć powyższe twierdzenia z naturalistyczną, mechanistyczną filozofią przyrody, która dała początek materializmowi epoki Oświecenia. Ta część filozofii kartezjańskiej, utrzymuje francuski neotomista, cechuje się bowiem wyraźną pragmatyzacją poznania: odtąd człowiek jako „istota myśląca” ma przede wszystkim dążyć do opanowania natury. Sam natomiast świat, obraz świata, stając się jasny i wyraźny dla rozumu ludzkiego, przedstawia się jako całkowicie racjonalny, albowiem jest stwarzany przez sam rozum i na jego miarę. Takie zaś uznanie niezależności rozumu ludzkiego na podobieństwo anielskie, na obraz ducha czystego, wiedzie do idealizmu i racjonalizmu. „Istota racjonalizmu - wnioskuje Maritain - polega na tym, że z rozumu ludzkiego i jego zawartości ideologicznej czyni się miarę tego, co jest"9. Dlatego też w innym miejscu może utrzymywać, że tak naprawdę racjonalizm jest „intelektualizmem wyobraźni”" Racjonalizm implikuje tedy naturalizm antropocentryczny, na który składają się optymizm antropologiczny oraz progresywizm, czyli doktryna postępu koniecznego, opierającego się na pragnieniu zbawienia człowieka przez naukę i rozum - a zatem jest to obietnica zbawienia ziemskiego. Podsumowując ten wątek, można więc powiedzieć, że tak ujmowany racjonalizm „jest śmiercią duchowości”11.

Tenże, Le songe..., dz. cyt., s. 85-86.

9 Tenże, Trzej reformatorzy. Luter, Kartezjusz, Rousseau, tłum. K. Michalski, Warszawa-Ząbki 2005, s. 127.

10 Tenże, Le songe..., dz. cyt., s. 69.

11 Tenże, Descartes et l'esprit..., s. 412; por. tenże, Le songe..., dz. cyt., s. 274. 
Ad 3. Co więcej, w zaproponowanej koncepcji człowieka Kartezjusz popełnia kardynalny, niewybaczalny błąd dualizmu antropologicznego. Właściwie na gruncie tej doktryny człowiek jawi się aniołem zamieszkującym maszynę, czystym umysłem zarządzającym ciałem. Dlatego też zachodzi w nim konflikt sfery świadomej (duszy) i nieświadomej (ciała), wolności i determinizmu. To stąd wynika dość pokaźna liczba „mitów metafizycznych" - takich jak okazjonalizm, idea harmonii przedustawnej, paralelizm spinozjański - próbujących na powrót łączyć to, co zostało u swych podstaw rozdzielone. Nic zatem dziwnego, że ów „zamach” na compositum humanum pociągnął za sobą tak długofalowe i niebezpieczne skutki. Doprowadził bowiem do intelektualizmu i deprecjacji życia afektywnego, a tym samym przyczynił się do alienacji cielesności i dehumanizacji ludzkiego ciała. W filozofii nowożytnej antropocentryzm i subiektywizm wyraziły się zarówno w stanowiskach racjonalistycznych, jak i empirycznych. W konsekwencji zaś dotychczas „oswojony” i „udomowiony” przez człowieka świat, stał się domeną technicyzacji i maszynizacji poszczególnych sfer rzeczywistości, co zresztą okazało się skuteczną metodą, służącą do jego wyobcowania i trwałej fragmentaryzacji: odtąd świat przemienił się w to, co zewnętrzne dla człowieka.

Skutki kulturalne dualizmu kartezjańskiego można więc przedstawić w postaci rozwidlającej się tendencji. Z jednej strony mamy do czynienia $\mathrm{z}$ angelizmem, który wytyczył historyczną ścieżkę idealizmowi, natomiast $\mathrm{z}$ drugiej - zostały $\mathrm{w}$ kartezjanizmie założone podwaliny pod materializm antropocentryczny, który w nieco późniejszym okresie doprowadził do materialistycznych stanowisk w filozofii oświeceniowej. Biorąc pod uwagę owo miejsce Kartezjusza w dziejach kultury europejskiej można zatem przyznać, iż rzeczywiście jest on „ojcem nowożytności", a raczej - błędów nowożytności. Gwoli ścisłości należy podkreślić, że zarzuty te Maritain formułuje raczej wobec kartezjanizmu jako systemu, a więc i wszelkich jego możliwych konsekwencji, niźli wprost kieruje je do samego filozofa. Niemniej jednak - w przekonaniu neotomisty - sam twórca systemu dopuścił się przewiny teoretycznej, która na trwałe naznaczyła dzieje filozofii europejskiej, i to dlatego kartezjanizm 
pozostanie na zawsze wielkim "grzechem francuskim”" Stał się on bowiem matecznikiem - chociaż nie jedynym, dodajmy - długiego szeregu błędów w filozofii: antyrealizmu, racjonalizmu, subiektywizmu, angelizmu, intelektualizmu, idealizmu, fideizmu, deizmu, panteizmu, ontologizmu, naturalizmu, empiryzmu, mechanicyzmu, technicyzmu, agnostycyzmu, antropoteizmu... Lista owa zdaje się nie mieć końca.

Uogólniając, i tym samym jednak dalece upraszczając, można stwierdzić, że w swej filozofii Kartezjusz łączył spirytualizm z nową filozofią natury. Ale w rzeczywistości to, co zdołał on osiągnąć, sprowadza się zaledwie do mniej lub bardziej ścisłego połączenia dwóch zasadniczych błędów, czyli „wypaczonego”, albowiem traktującego duszę ludzką na podobieństwo natury anielskiej spirytualizmu (angelizmu) z geometryczno-mechanistycznym ujęciem natury.

Co ciekawe, zapewne robiąc też ukłon w stronę rosyjskiej części audytorium, filozof francuski wyrażał przekonanie, że do zażegnania kryzysu współczesności - podkreślmy to raz jeszcze: wynikającego z walki dwóch pryncypiów, czyli anielskiego człowieka czystych idei i materialistycznego monstrum ciemności - może przyczynić się religijna filozofia rosyjska, która wnosi do świadomości europejskiej zasadę teandryczną. Oczywiście ze swojej strony myśliciel francuski proponuje jednak oprzeć się na ,jedynym prawdziwym systemie”, realizmie tomistycznym.

\section{Wyszesławcew i Absolut kartezjański}

$\mathrm{Na}$ całkowicie inną perspektywę otwiera się stanowisko Wyszesławcewa ${ }^{13}$. Można przyjąć, że podstawą i rozwinięciem (w pewnym zaś zakresie po prostu powtórzeniem) głównych idei paryskiego wystąpienia rosyjskiego filozofa są jego rozważania sformułowane mniej więcej w tym samym czasie, co i przywoływana dyskusja, zawarte na

12 Tenże, Descartes et l'esprit..., dz. cyt., s. 417; tenże, Le songe..., dz. cyt., s. 287; tenże, Trzej reformatorzy..., dz. cyt., s. 128.

13 Por. L. Augustyn, Wolność w jedności? Borys Wyszesławcew i rosyjska filozofia sobornosti, Kraków 2012, s. 93-95. 
stronicach Etyki przeobrażonego Erosa, oraz rosyjska wersja wystąpienia, która została zamieszczona w jego ostatniej, pośmiertnie wydanej książce $O$ tym, co wieczne $w$ filozofii ${ }^{14}$. Stwierdzić więc wypada, że filozofia Kartezjusza stanowiła dla rosyjskiego myśliciela stałe odniesienie. Oczywiście w związku z tym można mówić o wierności pierwotnemu rozpoznaniu, ale i przeciwnie - formułować zarzut, dotyczący braku immanentnego rozwoju stanowiska filozoficznego. Pozostańmy jednak przy pierwszej części tej uwagi, albowiem istotnie - w naszym przekonaniu - odpowiada ona rzeczywistości i dość dobrze określa charakter myślenia Wyszesławcewa.

Streśćmy wpierw tezy tej swoistej, Wyszesławcewowskiej „apologii Kartezjusza”. Jak zatem filozof podkreślał, celem omawianego wystąpienia było ukazanie doniosłości tylko „pewnej strony” stanowiska Kartezjusza, czyli nie kartezjanizmu ujmowanego in toto, lecz jego konkretnych i konstytutywnych elementów. Innymi słowy, chodziło o to, co należy bezwzględnie uznać za najcenniejsze w bogatej spuściźnie Kartezjusza zarówno dla rosyjskiej, jak i światowej filozofii, ale także - o czym w żadnych okolicznościach nie należy zapominać - przyszłości myślenia filozoficznego tout court. A tym, co stanowi w niej najwartościowsze jądro, jest, jak utrzymywał, swego rodzaju „objawienie filozoficzne”, intuicja fundamentalna ${ }^{15}$. Spróbujmy ją odsłonić, dokonajmy więc prostej redukcji wielości treści „kartezjanizmu” i tym samym spróbujmy wskazać na ich podstawę - tego wszak domagał się rosyjski myśliciel. Przekonywał mianowicie, że nie istnieje godna tego miana filozofia, która nie opierałaby się na metodzie intuicyjno-dialektycznej (najwyraźniej mamy w tym określeniu do czynienia z platońskim sposobem rozumienia tego,

14 B. P. Wyszesławcew, Etika prieobrażennogo Erosa. Probliema Zakona i Błagodati (1931); tenże, Wiecznoje w russkoj fiłosofii (1955). Obydwie książki zostały m.in. opublikowane w jednotomowym wydaniu dzieł filozofa: Krizis industrialnoj kultury. Izbrannyje soczinienija, Moskwa, 2006. Z tej edycji korzystamy w niniejszym szkicu.

15 O „objawieniu Kartezjusza” pisał również Lew Szestow, który jednakże zarzucił francuskiemu filozofowi, iż ten natychmiast zasłonił prawdę objawioną, czyli sum („jestem”; „on, Kartezjusz, jest”). Ową przesłoną okazało się samo wnioskowanie (samo ergo), rozum. Por. L. Szestow. Na szalach Hioba. Duchowe wędrówki, tłum. J. Chmielewski, Warszawa 2003, s. 145-146. 
czym jest filozofia). Kartezjańskie cogito, ergo sum odpowiada dokładnie takiej metodzie i w porządku myślowym (ale także egzystencjalno-faktycznym) stanowi to, co pierwsze, a zatem musi też poprzedzać wszelką dedukcję. Ale żeby dojść do tego pierwotnego „odsłonięcia”, Kartezjusz musiał posłużyć się metodą redukcyjną (później określoną mianem fenomenologicznej). Metoda redukcyjna łączy się ponadto z pojęciem transu, przekroczenia, a więc wyjścia poza „dany” i „zastany” poziom świadomości: każda prawdziwa filozofia rodzi się bowiem z transu; bez dążenia do przekroczenia tego, co każdorazowo dane, nie można nawet mówić o poznaniu filozoficznym ${ }^{16}$. „Dany” jest zatem świat fenomenalny, sfera idei, ale „dane” jest również Ja. Idee istnieją dla Ja, są więc fenomenami. Realność rzeczy opiera się na fenomenach, ich pewność sprowadza się do „prostej obecności” (Włodzimierz Sołowjow). Przynależną natomiast ludzkiemu Ja pewność odnajduje ono w swym ukierunkowaniu na siebie, we własnym „przeżyciu”. Prawdziwe są zatem - jak to ujmował Bergson - „bezpośrednie dane świadomości”. Cogito obejmuje tedy świadomość wraz z wszystkimi jej bezpośrednimi danymi. Ale, co najważniejsze, Ja opiera się takiej redukcji do fenomenów, dlatego też można wnioskować, że mamy tutaj do czynienia z „bytem innego wymiaru”, trzecim - obok rzeczy („ziemi przedmiotów”) i idei (ujawniających się w „słońcu podmiotu”) - wymiarem bytu. Warto przypomnieć, że po raz pierwszy intuicja ta znalazła wyraz w Platońskiej paraboli jaskini. W ten oto sposób, chociaż nie do końca „świadom tego, co czyni”, Kartezjusz odkrył „prawdę”, której znaczenie jednakże nie tylko przekraczało horyzont jego czasów, ale od tego momentu stało się wręcz klasycznym wyzwaniem dla myśli filozoficznej: istotową transcendencję Ego. To dlatego Wyszesławcew może zapytywać i natychmiast udzielać odpowiedzi: „Gdzie znajduje się owo «Ja»? Jest ono - w drugim wymiarze, w trzecim wymiarze - ponad potokiem przeżyć, i w końcu - na tym polega błąd Bergsona - poza przestrzenią i czasem"17.

16 B. P. Wyszesławcew, Etika prieobrażennogo..., dz. cyt., s. 153.

17 B. Vycheslavtzeff, Descartes et la philosophie moderne, [w:] Le Studio Franco-Russe, dz. cyt., s. 422; por. B. P. Wyszesławcew, Wiecznoje..., dz. cyt., s. 803. 
Najprawdopodobniej dokładnie w tym punkcie została więc osiągnięta nieprzekraczalna dla myśli granica: widz teatru, dopóki pozostaje tylko widzem, nie może oglądać siebie na scenie. A świat - jak wiemy - jest życiowym teatrem. Nie oznacza to bynajmniej, że już na tym etapie zostaliśmy zmuszeni do powstrzymania naszego ludzkiego, i przecież wciąż jeszcze filozoficznego zapytywania. Nic podobnego! - zastrzega się Wyszesławcew. Otóż transcendujący charakter Ja znajduje swe przedłużenie w problematyce Absolutu. Wiadomo, iż Kartezjusz po demonstracji Ja przeszedł do dowodzenia istnienia Boga. Rozważania egologiczne nie mogą zatem abstrahować od - wszakże na tym etapie zaledwie domniemanego - wymiaru absolutnego. Co prawda, spośród bytów składających się na świat, w sposób właściwy istnieje wyłącznie Ja, ale ujmowane w swej absolutnej samotności, w domkniętej pełni swojego istnienia, pozostawałoby ono tylko samozwańczym absolutem, a tym samym spełniałoby też kryteria konsekwentnego solipsyzmu. Ale rzeczywiste Ja nigdy nie istnieje w takiej samotności, gdyż tym, co je umożliwia i sprawia, że istnieje ono zawsze ku-innemu i ku-czemuś, jest właśnie jego zależność od Absolutu. Ja istnieje bowiem w sposób absolutno-względny. Stąd wyrasta, osadzone w pierwotnej intuicji Ja, przekonanie, że obok świata Ja (i w konsekwencji wielości Ja) istnieje Byt absolutny. Podobnie jak Ja, opiera się On wszelkiej redukcji do fenomenów i podobnie, jak to było w przypadku Ja, istnienie Boga jest samooczywiste (spotykamy tutaj wyraźny ślad ontologizmu w myśleniu Wyszesławcewa). Bóg ratuje człowieka przed absolutnościa, czyli nieznośną, bo nie na jego miarę, samotnościa.

Teraz możemy już w sposób nieco pełniejszy określić intuicję fundamentalną Kartezjusza, jaką odsłaniał i podkreślał rosyjski filozof: „Intuicja fundamentalna, która wskazuje na mój własny byt jako względny (nie-Absolutny), jest jednocześnie intuicją Bytu Absolutnego oraz intuicją mojej zależności, albowiem to, co względne, pozostaje w zależności od Absolutu, podobnie jak to, co skończone, pozostaje w zależności od tego, co nieskończone"18.

18 B. Vycheslavtzeff, Descartes et la philosophie..., dz. cyt., s. 423; por. B. P. Wyszesławcew, Wiecznoje..., dz. cyt., s. 804. 
Wyszesławcew uznaje zatem istnienie dialektyki zależności i wolności, zakłada konieczność jej przyjęcia. Niejako w myśl zasady: aby być rzeczywiście wolnym, musisz znać swoje istotne ograniczenia. Co więcej, tym, co wyzwala z błędnego koła solipsyzmu, jest właśnie aksjomat zależności lub aksjomat religii (w tej kwestii rosyjski myśliciel odwołuje się do filozofii religii Friedricha D. E. Schleiermachera), który można sprowadzić do świadomości: nie jestem sam prawdziwie istniejący. Wiemy bowiem, że po dokonanej - a po raz pierwszy zademonstrowanej przez Kartezjusza - redukcji pozostaje: Ja, które nie jest Absolutem i Absolut, który nie jest mną. W tym układzie Ja odznacza się zależnością, natomiast Absolut pozostaje w pełni niezależny. I to dlatego, rzec można, moja niezależność (wobec rzeczy, wobec świata) pochodzi od mojej zależności (od Absolutu). W konkluzji należy zatem przyjąć, że prawdziwa szansa zaistnienia mojej wolności (wolności Ja) wydarza się w przestrzeni wyznaczonej relacjami zależności i niezależności, pomiędzy ludzkim Ja i boskim Absolutem. Owo przejście od zależności do niezależności łączy się nie tylko z poczuciem wolności (byciem-wolnym-wewnątrz-świata), ale również chroni wolność przed „zakusami” świata, przed jego zniewalającymi siłami. Głównym niebezpieczeństwem grożącym sprawie wolności ludzkiej są bowiem wszelkiego rodzaju pseudoabsolutyzacje. W tej konfrontacji uznanie sfery absolutności ponadświatowej (Absolut-Bóg) staje się właściwie jedynie skutecznym sposobem na uniknięcie pułapek idolizmu, polegającego na przypadkowej i niczym nieuzasadnionej absolutyzacji tego, co względne. Wyzwolenie od świata, czyli potwierdzenie swej wolności w świecie, możliwe jest więc wyłącznie w relacji do ponadświatowego Absolutu. To dopiero absolutna perspektywa umożliwia przejrzenie fałszywych „absolutów”. W swej najgłębszej istocie byt ludzki, jako zakorzeniony w sferze absolutnej, jest zdolny do relatywizacji świata i nadawania każdej rzeczy jej tylko przynależnej miary. Człowiek jest istotą wątpiącą i dlatego - wolną. Je doute, donc je suis libre.

Rosyjski filozof nader chętnie przyznawał, że Kartezjusz podniósł umysł ludzki wysoko - ponad świat rzeczy i uczynił go tym samym wolnym, wzniósł go do poziomu aniołów; z czym, oczywiście, nie był w stanie pogodzić się Maritain. Ale właściwie - przekornie i prowokująco 
wobec francuskiego neotomisty kwestię tę ujmując - jest jeszcze gorzej: „Ego, umysł - podkreśla rosyjski myśliciel - jest nie tylko czymś anielskim, ale ponadto czymś boskim - obrazem Boga, tak jak i wolność jest obrazem Boga"19.

Pogłębiając swą charakterystykę, Wyszesławcew utrzymuje, że z rosyjskiego punktu widzenia filozofia Kartezjusza zawiera niezmiernie doniosłą przesłankę, a mianowicie przekonanie, że wspomniana intuicja Ja i Absolutu (bo w istocie jest jedną i tą samą) jest intuicją mistyczną i irracjonalną: „Owa więź z Absolutem pozostaje unikalną, tajemniczą, irracjonalną, niewyrażalną za pomocą kategorii przyczynowości, substancji i celu; to właśnie dlatego Kant ma rację wbrew Arystotelesowi i tomizmowi. Prawdopodobnie tylko symbole i mity religijne są w stanie wyrazić tę więź" ${ }^{20}$. Niemniej jednak przyznaje, że błędem francuskiego filozofa było uznanie obydwu jej stron za osobne substancje, rzeczy. W tym więc sensie Kartezjusz jest odpowiedzialny za powstanie i ugruntowanie racjonalizmu dogmatycznego (niejako zląkł się tego, co irracjonalne w nim samym). I stąd też wynikły dalsze jego błędy: rozbudował system dwóch substancji, przyjął automatyzm jako odpowiedź na zagadkę życia organicznego, opowiedział się za mechanicyzmem.

Trzeba zatem odróżniać Kartezjusza jako myśliciela źródłowego od Kartezjusza jako budowniczego systemu - kartezjanizmu. I wbrew owym fałszywym wnioskom, będącym w istocie tylko daninami na rzecz systemu, należy zwrócić się ku prawdziwym źródłom jego myślenia. Otóż zgodnie z Wyszesławcewowską interpretacją stanowiska kartezjańskiego, odsłaniany w kolejnych redukcjach (fenomenologicznej i absolutnej) aksjomat zależności zachowuje charakter na wskroś irracjonalny. I właśnie w tym - wszakże zasadniczym - punkcie nie można upatrywać żadnej możliwości porozumienia między myślą kartezjańską i tomistyczną; tak więc zarówno „interpretacja rosyjska”, jak i „interpretacja francuska”

19 B. Vycheslavtzeff, Descartes et la philosophie..., dz. cyt., s. 426; por. B. P. Wyszesławcew, Wiecznoje..., dz. cyt., s. 808.

20 B. Vycheslavtzeff, Descartes et la philosophie..., dz. cyt., s. 425; por. B. P. Wyszesławcew, Wiecznoje..., dz. cyt., s. 807 (w wersji rosyjskiej zastrzeżenie dotyczące „prawdopodobieństwa” nie występuje). 
nie znajdują wspólnej im podstawy, a w związku z tym i Wyszesławcew, i Maritain muszą pozostać na swych wyjściowych pozycjach.

I dlatego też nie w stronę neotomizmu, lecz fenomenologii spogląda Wyszesławcew. Jak bowiem podkreślał, współczesna (wystrzegajmy się jednak ahistoryzmu: ówczesna myślicielowi) fenomenologia opiera się na interpretacji cogito Kartezjusza ${ }^{21}$. Nie ujmuje ona jednak (albowiem nie chce lub nawet nie jest w stanie tego uczynić) wszystkiego tego, co z punktu widzenia rosyjskiego filozofa pozostaje u Kartezjusza najwartościowsze. A właściwie - rozmija się w jednej, ale za to zasadniczej sprawie. Otóż podstawowa różnica w rozumieniu zakresu stosowalności redukcji, jaka zachodzi między myślicielami rosyjskimi i Husserlowską fenomenologią, sprowadza się do filozoficznego statusu Absolutu-Boga. W interpretacji rosyjskiej - utrzymuje myśliciel - cogito jest ujmowane na sposób ontologiczny, absolutny, mistyczny i - nie omieszka dodać - dużo bliższy samemu Kartezjuszowi ${ }^{22}$. Ja i Absolut, byt ludzki i byt boski stanowią tedy dwie i w istocie nieodłączne strony intuicji fundamentalnej. Ich współwystępowanie i współzależność (chociażby ujęta jednostronnie) wyznacza sferę tego, co nieredukowalne. Inaczej natomiast to samo zagadnienie wygląda u Husserla, który uznaje możliwość redukcji Absolutu-Boga. Tymczasem już przyjęcie takiej możliwości redukcji staje się równoznaczne z opowiedzeniem się po stronie ateizmu i, co gorsza, pociąga za sobą nader niebezpieczne konsekwencje. Wyszesławcew pozostaje bowiem przekonany, że tak naprawdę - duchowo i intelektualnie - jest to przedsięwzięcie zgoła niemożliwe: każda negacja Absolutu, ustanawiająca nicość absolutną, stanowi tylko jedną ze stron Absolutu (mamy wszak do czynienia z „nieznanym” Bogiem - Deus absconditus). Wszelka więc próba zanegowania Absolutu i odpowiadające jej in praxi różne odmiany ateizmu $\mathrm{z}$ nieuniknioną konsekwencją zmierzają do idolatrii, ustanawiają jedną z niezliczonych

21 Zapewne uwagi te były pokłosiem paryskich wykładów E. Husserla (wygłoszonych na Sorbonie 23 i 25 lutego 1929 roku), które legły u podstaw Medytacji kartezjańskich (1931).

22 B. Vycheslavtzeff, Descartes et la philosophie..., dz. cyt., s. 425; por. B. P. Wyszesławcew, Wiecznoje..., dz. cyt., s. 806 . 
form idolizmu. Można więc rzec, że podmiotowość Ja domaga się stałego odniesienia do tego, co dla niej samej konstytutywne - nieredukowalności (scil. absolutności) istnienia.

Wniosek, będący zadaniem, przed którym stoi myśl współczesna, sprowadza się zatem do wymogu zniesienia kartezjanizmu, ale tylko po to, aby odsłonić prawdziwą - zarówno dla filozofii, jak i kultury współczesnej - wartość Kartezjusza. Wbrew bowiem zdaniu Maritaina, Kartezjusz na zawsze pozostanie „wielką chwałą Francji”'23.

\section{Odpryski dyskusji}

W trakcie dyskusji Bierdiajew dał wyraz swojemu zdziwieniu, że to właśnie Rosjanin musiał bronić Kartezjusza przed atakiem ze strony Francuza (a podobne zdanie wygłosił też Désiré Roustan). To, co istotne i zarazem wartościowe w spuściźnie kartezjańskiej, to wyraźne postawienie „problemu podmiotowości”. Uznając się za antykartezjanina, Bierdiajew starał się jednak bronić Kartezjusza z historiozoficznego punktu widzenia. Przyjmował więc, że wystąpienie Kartezjusza było doniosłym „aktem w europejskim dramacie świadomości filozoficznej”. Co prawda nie zgadzał się z interpretacją autorstwa Wyszesławcewa, bowiem Kartezjusz nie był mistykiem, niemniej w zaproponowanym ujęciu ważne było wskazanie na to, że filozofia ducha jest całkowicie innym typem filozofii niż filozofia przedmiotu. „Filozofia ducha - podkreślał - stała się możliwa po Kartezjuszu, chociaż u niego samego jeszcze nie istnia$\mathrm{la}^{24}$. Filozof francuski postawił zatem problem, albo inaczej rzecz ujmując - stworzył warunki do zaistnienia i rozwinięcia nowożytnej koncepcji ducha ludzkiego. Co się zaś tyczy wpływu jego racjonalistycznego systemu na kulturę europejską, to można zgodzić się z zarzutami Maritaina: ultraracjonalizm kartezjański wyrządził jej bowiem wiele szkód, ale nie należy też obarczać nimi wyłącznie samego Kartezjusza.

23 B. Vycheslavtzeff, Descartes et la philosophie..., dz. cyt., s. 428; por. B. P. Wyszesławcew, Wiecznoje..., dz. cyt., s. 809.

${ }_{24}$ Les débats, [w:] Le Studio Franco-Russe, dz. cyt., s. 431. 
Oczywiście, na tak sformułowane wnioski nie mógł się zgodzić francuski neotomista. Bierdiajewowskiej perspektywie historiozoficznej przeciwstawiał on ponadhistoryczny, filozoficzny „prawdziwy system”, zawierający w sobie także filozofię ducha.

Ważny głos w dyskusji przynależał do Léonida Gabrilovitcha, uprawiającego tę tak niepochlebnie ocenioną przez Raïssę Maritain profesję, czyli dziennikarstwo (notabene przed rewolucją wykładającego filozofię na Uniwersytecie Petersburskim), ale parającego się również krytyką literacką i teatralną. Dotyczył on przede wszystkim Maritainowskiego zarzutu antropoteizmu, a tym samym kwestii początków nowożytnego procesu sekularyzacji filozofii. Niewątpliwie należy przyznać, że Kartezjusz poddaje sekularyzacji filozofię. Ale - zapytuje - czy jest to działanie przeciwko religii? Można nawet powiedzieć, że Kartezjusz nie był dość radykalny w zerwaniu $\mathrm{z}$ tradycją scholastyczną; jego filozofia pozostawała jeszcze w bezpośredniej zależności od Boga obiektywnego, boskiej substancji. Istnieje zatem potrzeba doprowadzenia tej tendencji do końca: przeprowadzenia integralnej sekularyzacji filozofii i życia. Czyż to nie za sprawą Kartezjusza mógł zrodzić się bowiem „nowożytny człowiek wewnętrzny”, odpowiednik „Chrystusa wewnętrznego” (o czym przecież od dawna mówili wielcy mistycy, w tym przede wszystkim Paweł z Tarsu), czyli Bóg uwolniony od swych urzeczowionych pojęć? Trzeba zatem kontynuować ten wskazany kierunek i uniezależniać religię od presji zewnętrzności, oswobadzać ducha ludzkiego ${ }^{25}$.

Jak łatwo się domyślić, takie z gruntu modernistyczne stanowisko Gabrilovitcha nie mogło znaleźć uznania u nieprzejednanego tomistycznego antymodernisty.

Odpowiedź Maritaina, dotycząca interpretacji zaproponowanej przez Wyszesławcewa, dotykała sprawy dla obu myślicieli zasadniczej: intuicji Absolutu. Tak więc, odnosząc się do tego zagadnienia, podkreślał on, że myśliciela rosyjskiego nie można uznać za ortodoksyjnego fenomenologa, gdyż podstawowe pojęcie „czystej świadomości”, które spotykamy na gruncie fenomenologii, bynajmniej nie odpowiada 
przedstawionej przez niego koncepcji Ego i mistycznej intuicji Absolutu ${ }^{26}$. Poniekąd zgadzając się $\mathrm{z}$ tym zarzutem, należałoby jednak dodać, że Wyszesławcew skupił się raczej na wykładzie własnej koncepcji „redukcji absolutnej” (na co też explicite wskazywał), niż na próbie uzasadnienia historycznej prawomocności związku myśli kartezjańskiej z fenomenologią. Nie jest pozbawiona przecież nieco prowokującego charakteru głoszona przezeń teza, iż to dopiero Kartezjusz zdołał za pomocą swego „redukującego wejrzenia” odsłonić źródłową wolność ducha: mistyczną głębię podmiotu ludzkiego. Tę niewyczerpalną studnię, w którą wciąż jeszcze wpatruje się, poddana swoistej autohipnozie, współczesna myśl fenomenologiczna ${ }^{27}$. Nawiązując zaś do Wyszesławcewowskiego sposobu rozumienia metody filozoficznej - jak pamiętamy, łączącej intuicję z dialektyką - można by zapewne stwierdzić, że w oczach rosyjskiego myśliciela Kartezjusz jawi się przede wszystkim jako dialektyczny mistyk.

\section{„Rewolucja kartezjańska”}

Maritain mówił wręcz z niesmakiem o zwyrodnieniu rozumu człowieka nowożytnego: „[...] zażądaliśmy dla naszego intelektu doskonałej autonomii i doskonałej immanencji, bezwzględnej niezależności, aseitas intelektu niestworzonego”. Jednocześnie konkludował, że żądanie to: „[...] jest ukrytą przyczyną rozkładu naszej kultury i choroby, na którą Zachód - odstępca, umiera"28. I chociaż słowa te sformułował kilka lat przed paryskim wystąpieniem, to wyrażonym w nich przekonaniom pozostał odtąd już na stałe wierny. Wobec tak surowego osądu Wyszesławcew mógłby zapewne odpowiedzieć: „Tak, właśnie - autonomia!”. W niej wszakże upatrywał on szansy na odrodzenie kultury europejskiej, a główną zasługę, polegającą na nadaniu jej nowożytnego, w tym i współczesnego, kształtu, przypisywał

26 Les conclusions, [w:] Le Studio Franco-Russe, dz. cyt., s. 452-453.

27 Por. B. Vycheslavtzeff, Descartes et la philosophie..., dz. cyt., s. 426; por. B. P. Wyszesławcew, Wiecznoje..., dz. cyt., s. 807.

28 J. Maritain, Trzej reformatorzy..., dz. cyt., s. 120 i 121. 
Maritainowskiemu podsądnemu - Kartezjuszowi. W ten sposób francuski zarzut przemieniał się w rosyjską pochwałę.

W przekonaniu francuskiego neotomisty reforma kartezjańska była na tyle głęboka, że w swych konsekwencjach stała się rozciągniętą w czasie, obliczaną na stulecia rewolucją kulturalną ${ }^{29}$. Wyszesławcew zgadzał się, że w tym wypadku mieliśmy i nadal mamy do czynienia z duchowo-intelektualną rewolucją, niemniej wciąż jeszcze postaje ona rewolucją niedokończoną (a może, dodajmy od siebie, wręcz powinna taką pozostać - duchową, permanentną rewolucją?). I w tej również kwestii Rosjanin mógłby odpowiedzieć Francuzowi: „Ależ skąd, wspomniana rewolucja zatrzymała się w pół drogi!" Jakkolwiek by zatem nie było, to pozostaje prawdziwym stwierdzenie, że zarówno Maritain, jak i Wyszesławcew (a poniekąd i Bierdiajew, i Gabrilovitch) postrzegali Kartezjusza właśnie w charakterze „rewolucjonisty filozoficznego", chociaż już odmiennie, a nawet przeciwstawnie, oceniali sam charakter owej rewolucji. Maritain nie miał bowiem złudzeń co do skutków reformy kartezjańskiej: „Ponosi ona - podkreślał - w dużej części ciężar odpowiedzialności za bezgraniczną błahość nowożytnego świata i za tę przedziwną dolę, w której dziś pogrążyła się ludzkość, tym potężniej władająca materią, im jest słabsza i bardziej zagubiona wobec rzeczywistości duchowych, z którą dawniej łączyła ją pokora mądrości poddanej bytowi”30. Dla Wyszesławcewa zaś nie tyle był to dowód zerwania łączności świadomości z bytem, ile raczej skutek mylnego rozpoznania - albowiem prawdziwe źródło bytu, bijące w głębiach ducha ludzkiego, odsłania się dopiero w doświadczeniu wewnętrznym. Dlatego też rosyjski filozof nie szczędził zarówno gorących pochwał „Kartezjuszowi intuicyjnemu”, jak i surowych nagan dla „Kartezjusza racjonalistycznego”:

Kartezjusz odsłonił oczywistość irracjonalnego ego, pozostającego w irracjonalnej zależności od oczywisto-irracjonalnego Absolutu, ale z irracjonalnościami tymi nie umiał dać sobie rady, i dlatego owo tajemnicze ego natychmiast przekształcił w przedmiot poznania racjonalnego, rzecz, substancję (res cogitans), a jednocześnie

29 Tenże, Le songe..., dz. cyt., s. 37.

30 Tenże, Trzej reformatorzy..., dz. cyt., s. 122. 
z Absolutu uczynił substancję, czyli przedmiot poznania racjonalnego; zapominając przy tym, że cała wartość i wszelki sens jego znakomitej demonstracji „ego cogito” zawiera się w tym, że ego i Absolut absolutnie przekraczają świat cały, i dlatego przenigdy nie mogą być traktowane jako przedmioty, rzeczy, substancje. Potrzeba było dopiero Kanta, kantyzmu i fenomenologii, aby wskazać jego pomyłki i przedstawić genialną „redukcję fenomenologiczną” Kartezjusza w całej jej czystości. W końcu, potrzeba było również współczesnego irracjonalizmu Rudolfa Otto - aby aksjomat zależności wyzwolić z więzienia racjonalizmu ${ }^{31}$.

Tak więc w porządku metafizycznym doświadczenie istnienia poprzedza doświadczenie świata, a zatem należy również przyjąć, że to dopiero doświadczenie duchowe (,ja i Absolut”) umożliwia poznanie rzeczywistości („ja i świat”). W perspektywie myślenia Wyszesławcewa jawi się tedy Kartezjusz jako mistrz nowożytności, przesuwający zainteresowanie filozofii z „przedmiotowej” na jej „podmiotową" stronę. A zatem byłby też filozofem niejako pomagającym kulturze nowożytnej zrozumieć samą siebie i, co więcej, na własnym przykładzie pokazującym zarówno jej duchowo-podmiotowe źródła, jak i racjonalistyczno-obiektywistyczne wypaczenia. W związku z tym, zgoła inaczej niż Maritain, rosyjski myśliciel postrzegał miejsce Kartezjusza w kulturze i w zasadniczy sposób różnił się w ocenie istoty i charakteru jego filozofii, widząc w nim przede wszystkim intelektualnego fundatora nowożytnej świadomości.

Filozoficzna, duchowo-intelektualna perspektywa Maritaina - mimo swej retrospektywności - była natomiast ześrodkowana na intelektualnych i, rzecz jasna, filozoficznych źródłach współczesnych problemów. Stałym dla niej odniesieniem pozostaje jedność bytu i myśli, wiary i rozumu. Jednym ze wspomnianych problemów współczesności było dlań właśnie dziedzictwo kartezjańskie, stojące wszakże w bezpośredniej opozycji do tradycji (neo)tomistycznej. To stąd zrodziła się wynikała paląca konieczność zwalczenia owych szeroko rozpowszechnionych w świecie „plag kartezjańskich”. W opozycji do zanurzonej w czasie nowożytności wskazywał więc na ponadhistoryczny ideał średniowieczny: teologiczno-filozoficzny 
system Doktora Anielskiego. Ale na to z kolei nie mogła, i to nie tylko w ramach tej dyskusji, przystać „strona” rosyjska. Nie wspominając, rzecz jasna, oburzenia niektórych Francuzów, dla których Francja w ogóle nie istnieje bez Kartezjusza i tradycji kartezjańskiej (np. René Lalou) ${ }^{32}$. Dla dyskutantów rosyjskich (jakkolwiek mówimy o indywidualnościach zajmujących specyficzne, a niekiedy nawet osobne miejsca w kulturze emigracji rosyjskiej) otwarcie się na tradycję zachodnią dokonało się już na innych poziomach: wiele dla tej sprawy starał się też czynić Wyszesławcew. Jednakże, spoglądając z Maritainowskiego punktu widzenia, jego błędem było opowiedzenie się za irracjonalnym źródłem filozofii - nie tylko kartezjańskiej, lecz filozofii tout court. W oczach francuskiego neotomisty taki irracjonalizm filozoficzny mógł co najwyżej uchodzić za pseudofilozoficzny wyraz zasady szkodliwej - chociaż zrodzonej na rodzimej glebie - wobec prawdziwej, klasycznej, myśli europejskiej, a tym samym stanowił on nader destrukcyjną siłę dla tworzonej i wciąż od nowa zagrożonej cywilizacji europejskiej („katolickiej”). Innymi słowy, irracjonalizm był postrzegany przezeń jako wypaczona u swych źródeł tendencja duchowa, zrywająca z bytem i w konsekwencji niszcząca rozum ludzki. Jeszcze wiele lat później utrzymywał, że niezmienne, czyli transcendentne wartości stały się u „ojca nowożytności” jedynie „przygodnymi tworami boskiej wolności” i z tego względu należałoby je uznać za immanentne, relatywne i ateistyczne pseudowartości ${ }^{33}$. A zatem i w tym przypadku Maritain dążyłby do wpisania Wyszesławcewowskiej interpretacji w ramy uprzednio przyjętego przezeń wzorca. O ile więc u Kartezjusza - jak zdawał się twierdzić Wyszesławcew - mamy do czynienia z irracjonalistyczną podstawą racjonalizmu (a w tym wypadku neotomista mógłby mówić o czysto woluntarystycznym podłożu doskonale przejrzystego rozumu), o tyle też „ojciec nowożytności” - przekonuje Maritain - otworzył filozoficzną puszkę Pandory, w wyniku czego na świat wydostały się owe niezmiernie groźne „plagi kartezjanizmu”. Otóż, jak wiemy, właśnie na tych

32 Por. Les débats, dz. cyt., s. 443.

33 Por. J. Maritain, Sens wspótczesnego ateizmu, tłum. A. Ziernicki, „Znak”, 1990, nr 424(9), s. 6. Tekst pochodzi z 1949 roku. 
negatywnych konsekwencjach starał się skupić w swym wystąpieniu neotomista francuski. A wskazując na nie, popadał niewątpliwie przy tym w swoistą emfazę i chyba jednak retoryczną przesadę.

W ocenie zaś Wyszesławcewa główna słabość Kartezjusza polegała na scholastycznych pozostałościach stworzonego przezeń systemu, które doprowadziły do substancjalizacji pojęć Boga i rozumu ludzkiego. Wolność nowożytna domagała się jednak swego wyrazu: pojęcia rozumu są tylko formami pierwotnej wolności, które z kolei odsyłają do swych podmiotowych, irracjonalnych źródeł. W przeciwnym bowiem wypadku - odcinając się od własnych korzeni - wyradzają się w czysty racjonalizm. To prawda - grzech ten popełnił Kartezjusz. Ale uczynił to dopiero w drugiej kolejności, wpierw zaś odsłonił dialektykę zależności i niezależności (aksjomat zależności), a tym samym wskazał na absolutny warunek i ludzką możliwość zaistnienia wolności podmiotowej. Innymi słowy, umożliwił zrodzenie się nowożytnej podmiotowości. Tak więc rosyjski filozof opowiadał się za myśleniem prospektywnym w filozofii, które jednakże obejmowałoby twórcze - duchowe: religijne i filozoficzne - osiągnięcia przeszłości, i jednocześnie pozostawałoby otwarte na problemy myśli współczesnej. Wbrew zatem nieugiętemu stanowisku Maritaina, podtrzymywał on tezę o pozytywnym, wręcz wyzwalającym, znaczeniu myśli Kartezjusza dla nowożytnego człowieka.

\section{Uwaga końcowa}

Zamykając te rozważania, warto podkreślić, iż w tle omawianej dyskusji filozoficznej toczył się także spór cywilizacyjny ${ }^{34}$. Jakkolwiek

34 O czym chociażby mogłaby świadczyć książka Défence de l’Occident (1927) Henri Massisa, człowieka przez pewien czas dość bliskiego Maritainowi. Jej autor sprowadzał ówczesne zmagania cywilizacyjne w Europie do walki dwóch zasad - azjatyzmu (germanizmu, slawizmu) i latynizmu, w ramach której „postępowi” i „siłom podziału” przeciwstawiał „ideał doskonałości i jedności”; ten francuski teoretyk „,antagonistycznej wizji cywilizacyjnej” upatrywał więc możliwości przekroczenia błędów nowożytności w powrocie do ideału średniowiecznego i jego religijnego (katolickiego) ożywienia. Por. H. Massis, Défence de l'Occident, Paris 1929, s. 256. Wydaje się, że w tym kontekście Wyszesławcewowska interpretacja filozofii Kartezjusza mogłaby wręcz uchodzić za teorię naznaczoną skazą germanizmu i slawizmu (będącymi en masse forpocztą azjatyzmu w Europie); zresztą również więk- 
nie dość wyraźnie zaznaczony, nadawał jej zewnętrzne ramy: wszak dotyczył nie tylko kwestii abstrakcyjnych, ale również duszy współczesnej cywilizacji, jej wartości i dróg ich realizacji. Samoświadomości człowieka i świadomości jego miejsca. A jak się domyślamy, takiej perspektywy, takich właśnie, mniej lub bardziej jawnych odniesień, nie mogło zabraknąć w trakcie dyskusji, prowadzonych w Studio franco-russe. Problem ten miał chyba duże znaczenie, gdyż sama dyskusja toczyła się w czasach głębokiego kryzysu.

Początek lat trzydziestych XX wieku niejako wymuszał na filozofach „myślenie w obliczu kryzysu”. Poszukiwanie intelektualnych i duchowych źródeł kryzysu, ale przecież również środków do jego przezwyciężenia, stało się bowiem wyzwaniem chwili. W ujęciu Maritaina, u podstaw tak ciężkiego kryzysu nowożytności, którego kulminacji nie sposób nie dostrzec w kulturze europejskiej pierwszych dekad XX wieku (a wiemy, że okres ten uległ wydłużeniu), leży tylko pozornie odległa w czasie rewolucja kartezjańska. Wyszesławcew zaś, wprost przeciwnie, dostrzegał w „pozytywnej stronie” filozofii Kartezjusza (chociaż - trzeba podkreślić - już nie w kartezjanizmie) ciągle jeszcze niezrealizowaną w pełni szansę na odrodzenie ducha europejskiego.

szość pozycji z Maritainowskiego katalogu „plag kartezjańskich” znalazłaby w tej wizji swoje poczesne miejsce. Co ciekawe, w 1922 roku Wyszesławcew zarzucał O. Spenglerowi, że ten nie dostrzegł „nurtu irracjonalizmu” w Europie, zwłaszcza w myśli Bergsona (dodajmy: ważnego, acz porzuconego mistrza Maritaina) i dlatego popadł w historiozoficzny pesymizm. Por. B. P. Wyszesławcew, Zakat Jewropy (Ob Oswaldie Szpienglierie), [w:] N. A. Bierdiajew, Padienije swiaszczennogo russkogo carstwa. Publicistika 1914-1922, Moskwa 2007, s. 955 (w dziale: Priłożenija). Przypomnijmy ponadto, iż w 1927 roku ukazała się francuska wersja eseju Bierdiajewa Nowe średniowiecze (Un nouveau Moyen Age), co zapewne może stanowić istotne dopełnienie zagadnienia. 